\title{
The post-listing performance of new listings: A study on the JSE
}

\author{
D.J. Bradfield ${ }^{\star}$ and B.G. Hampton \\ Department of Mathematical Statistics, University of Cape Town, Private Bag, Rondebosch 7700 \\ Republic of South Africa
}

Accepted September 1988

\begin{abstract}
The authors examine the post-listing performance of new isues on the JSE. On the basis of an empirical study conducted over the 1975-1986 period, evidence is presented indicating that abnormal returns do occur during the post-listing period. The existence of hot and cold issue periods are also found to be evident on the JSE and the performance in the aftermarket is found to differ substantially in these periods. In hot issue periods abnormal returns are found in almost the entire 12 -month period subsequent to listing, with excess returns reaching as much as $7 \%$ per month during the subsequent year. The results for cold issue periods by contrast reveal abnormal returns only up to the first three months after issue, whereafter substantially negative returns occur in several subsequent months. Significant positive relationships were also evident between the opening premia and some important behavioural characteristics in the aftermarket, namely, abnormal returns one year after issue and volumes traded in the aftermarket.
\end{abstract}

Die outeurs ondersoek die nagelyste vertoning van nuwe uitgifte op die JEB. Gebaseer op 'n empiriese studie oor die periode 1975-1986, word getuienis gelewer om an te dui dat abnormale verdienste bekom word gedurende die nagelyste periode. Daar is gevind dat oorverhitte en oorverkoelde periodes bestaan op die JEB en dat die nagelyste vertoning substansieel verskil tussen hierdie periodes. In oorverhitte periodes word abnormale verdienstes gevind in bykans die hele 12-maande-periode na die uitgif met abnormale verdienstes tot soveel as $7 \%$ per maand gedurende die volgende jaar. Die resultate vir oorverkoelde periodes lewer in teenstelling daarmee, abnormale verdienstes slegs tot en met die eerste drie maande na die uitgif, waarna abnormale negatiewe verdienstes plaasvind in verskeie daaropvolgende maande. Betekenisvolle positiewe verwantskappe is gevind tussen die openingspremies en sommige belangrike eienskappe in die nagelyste periode, naamlik, abnormale verdienste een jaar na uitgif en volumes verhandel in die nagelyste periode.

*To whom correspondence should be addressed

\section{Introduction}

Recently evidence has come to the fore which reveals that unseasoned equity issues (commonly referred to as new listings) have exhibited a substantial opening premia relative to their issue price. Barlow \& Sparks (1986) presented evidence suggesting that opening premia on the Johannesburg Stock Exchange (JSE) in particular, have been substantially larger than those in the UK, USA, France and Japan. It is not clear however whether these equities on the JSE continue to exhibit superior excess returns in the short to medium post-listing period, or whether price adjustment is rapid.

This paper investigates the post-listing performance of new listings on the JSE over the period 1975-1986. The first section of this paper reviews the results of relevant studies conducted on the London Stock Exchange (LSE), the New York Stock Exchange (NYSE) and the JSE. In the second section the empirical analysis is conducted. Several aspects of post-market performance are investigated in this section. Firstly the short to medium post-listing (aftermarket) period will be under scrutiny to ascertain whether significant abnormal returns exist in the aftermarket. Secondly the existence of hot and cold issue periods on the JSE will be tested with a view to investigating the aftermarket performance in these periods. Thereafter the relationship between the magnitude of the opening premia and various share characteristics in the aftermarket, namely, excess returns, trading volumes and systematic risk are established. In the last section the hypothesis that performance in the aftermarket is related to the underwriter in question is investigated. Finally conclusions and implications of our findings are offered.

\section{Review of results}

Results on the LSE

Harris (1933) conducted the first extensive study on the post-market performance during the 1928 new issue boom on the LSE. Harris found that during the subsequent three-year period seasoned issues substantially outperformed the unseasonal issues. This subsequently led to a tightening of the LSE's listing requirements. Scott (1971) by contrast found that new issues listed on the LSE during 1965 outperformed the market by a mere $1 \%$ over a subsequent one and four-year period.

Evidence presented by Davis \& Grant (1972) showed that in five out of six years ranging from 1965 to 1970 new issues had a positive average excess return during the subsequent one-year period, and that there was a slight tendency for smaller firms to outperform larger firms. Williams (1972) examined the longer term performance of a sample of new issues over the 1966 to 1970 period, he found an average excess retum of $6 \%$ and $0,7 \%$ during the subsequent one-year and two-year periods respectively. The results of a study by Rothman (1973) using a time series of price relatives (with the FTA index) shows superior performance of new listings up to 18 months subsequent to listing. Vaughan, Grinyer \& Birley (1977) evaluated the aftermarket performance of LSE unseasoned issues on an accounting basis during 
the 1966-1974 period. They found that unseasoned issues had much higher returns on assets than seasoned issues and that on average the annual rate of profit growth in their first four years was double that of seasoned issues.

\section{Results on the NYSE}

The first study on the NYSE in this field was conducted by Stigler (1964) during the 1923-1928 period as well as the 1949-1955 period. He found that the market-adjusted price performance of new issues was on average negative for each of the subsequent five years for both the abovementioned periods. Contrary to these results a simple comparison of average return of new issues with the Dow-Jones Index by Reilly \& Hatfield (1969) taken at one week, four week and one year intervals subsequent to listing during 1964 and 1965 showed substantial gains of new issues over the Dow-Jones Index on a non-risk adjusted basis. Blum (1971) as well Logue (1973) also documented excess abnormal returns for new listings during the 1965-1969 period.

Ritter (1984) examined his 'speculative bubble hypothesis' during the 1977-1982 period. The hypothesis implies that offer prices are set correctly but that high initial returns result from speculative excesses. Ritter argues that in theory there should be adjustment periods of sharp price drops in the aftermarket (when the 'bubble bursts'), however he found no evidence of this.

\section{Results on the JSE}

Relatively few studies, by contrast, have been conducted on the JSE. An early study by Richards (1935) on new listings and aftermarket performance unfortunately did not take market movement into account, hence the results will not be quoted here. A more recent study was conducted by Wood (1986) on a sample of 47 new issues on the JSE during the period January 1975 to May 1986. Although Wood documented an average negative return using the price on the first Monday after listing and the price a year after listing, no provision for systematic risk was however made. Wood concludes that overpricing occurs initially, giving rise to negative returns in the aftermarket.

Barlow \& Sparks (1986) concentrated on the opening premium of 105 new issues during the period 1972 to 1986. They found a mean opening premium of $32,1 \%$ during this period. By contrast the weighted average of the opening premia on major Exchanges other than the JSE was $16,7 \%$, i.e. substantially smaller over this period. Barlow and Sparks did not however investigate the aftermarket performance of unseasoned issues.

\section{Emprical evidence}

The data

This study includes all new listings that occurred on the JSE during the period May 1975 to August 1986. This amounted to 77 unseasoned issues. Details of these issues are summarized in the appendix. A time series of the relevant dayly, weekly and monthly price data was captured over the subsequent year from the listing date, as well as the corresponding JSE Overall index for each of the 77 shares

Details relating to the offer of these issues were extracted from the study conducted by Barlow \& Sparks (1986).

\section{Calculations of excess returns}

The methodology of interpreting returns in a riskadjusted framework is important in studies where returns cannot realistically be interpreted on their own without considering the concept of risk.

McDonald \& Fisher (1972) and Reilly \& Hatfield (1969) both assume a beta of unity for each security in their computations of excess returns in the aftermarket period. This is thought to be an over-simplification, especially for the South African case where shares historically exhibit a large range of betas. By contrast Ibbotson (1975) proposed an excess return model based on returns across time and securities (RATS). The RATS model is felt to be over-elaborate and the additional complexity is felt to be unwarranted in the context of the objectives here.

The well-known excess return model given below was used to estimate returns that were higher/lower than expected on the basis of the systematic risk, $\beta$, of the security, $j$ :

$$
E_{j t}=R_{j t}-\left(r_{f}+\beta_{j}\left(R_{m t}-r_{f}\right)\right)
$$

where $E_{j t}$ is the excess return on share $j$ at time $t ; \boldsymbol{R}_{j t}$ is the actual return on share $j$ at time $t ; r_{f}$ is the risk-free rate of interest; $\beta_{j}$ is the systematic risk of share $j$; and $R_{m}$ is the actual return on the market at time $t$.

Betas for each security were estimated using the wellknown market model, i.e. monthly returns regressed against the corresponding returns on the JSE Overall index for one year subsequent to the listing date.

Since several objectives requiring differing testing methodologies were investigated, the methodologies and results will be discussed separately below.

\section{Aftermarket performance}

Reilly \& Hatfield (1969) have suggested that price adjustment after listing continues in the longer term as the market recognizes and adjusts for underpricing of the offer price. This suggests positive excess returns in the aftermarket.

In order to assess the performance of new listings in the aftermarket, excess returns from each of the 77 new listings on the JSE were computed using model (1) over each of the following periods:

$(0-1)$ - Close of offer to closing price on first day of trading.

$(0-3)$ - Close of offer to closing price on Monday one year after listing.

(1-2) - End of first day of trading to Monday one month after listing.

(1-3) - End of first day of trading to Monday one year after listing. 
Table 1 Average excess return of the 77 issues during one year subsequent to issue

\begin{tabular}{lccccc}
\hline & Period & Period & Period & Period & Period \\
\cline { 2 - 6 } & $0-1$ & $0-3$ & $1-2$ & $1-3$ & $2-3$ \\
\hline Mean excess & & & & & \\
Return & $27,0 \%$ & $92,1 \%$ & $3,7 \%$ & $29,0 \%$ & $24,3 \%$ \\
statistic $^{1}$ & 6,07 & 5,17 & 1,51 & 2,93 & 2,67 \\
\hline
\end{tabular}

(2-3) - Monday one month after listing to Monday one year after listing.

The above periods are similar to those used by McDonald \& Fisher (1972) and Reilly \& Hatfield (1969).

Table 1 shows the mean and associated t-statistics of the excess return of the 77 new listings computed over the above periods.

Inspection of Table 1 shows that all the mean excess returns are positive and significantly greater than zero (at the 5\% level) with the exception of period 1-2 representing the excess return over one month subsequent to listing. The above evidence suggests that abnormal returns do exist in the aftermarket of new listings on the JSE.

Historically there have however been periods when new listings have been more active than others. Since the period under study covers an extensive period of 11 years it is worth considering whether it embodies periods of this nature, and if so, whether different results can be expected in the aftermarket during these periods.

\section{Hot and cold issue periods}

The existence of hot and cold issue periods was first considered by Ritter (1984) on the NYSE. Ritter found that significant differences existed between opening premia in hot and cold issue periods.

In order to establish whether this phenomenon exists on the JSE a similar methodology was used to that used by Ritter. By a cursory examination of the opening permia the period August 1985 to the end of the period of study, that is August 1986, was proposed as a potential hot issue period on the JSE. The potential cold issue period was proposed from May 1975 to July 1985.

Table 2 shows the relevant summarized statistics over the above-mentioned periods.

Even though opening premia for both periods in Table 2 are relatively large, the issue under consideration here is whether a statistically significant difference between the premia in the two proposed periods exist. In order to test this, an ammended t-test was used for the specific

Table 2 Hot and cold issue period statistics

\begin{tabular}{lcccc}
\hline $\begin{array}{c}\text { Market } \\
\text { State }\end{array}$ & $\begin{array}{c}\text { Mean opening } \\
\text { premium }\end{array}$ & $\begin{array}{c}\text { Standard } \\
\text { deviation }\end{array}$ & $\begin{array}{c}\text { Number of Annual rate } \\
\text { listings }\end{array}$ & of listings \\
\hline Hot issue & 48 & 46 & 40 & 36,9 \\
Cold issue & 25 & 24 & 37 & 3,7 \\
\hline
\end{tabular}

case where the sample variances are significantly different (Underhill, 1981: 257). The test yieided a $t$ value of 2,78 which is significant at the $1 \%$ level. This evidence suggests that hot and cold issue periods exist within which opening premia do differ significantly.

As stated earlier the existence of hot and cold issue periods is likely to impact diferently on the aftermarket performance of new listings in these periods.

In order to investigate this possible effect the excess returns over the first month for all issues in the hot issue period were averaged. This process was repeated for the second month and continued up to the twelth month after listing. This procedure was repeated for shares listed in the cold issue period.

The results for the hot issue are shown in Figure 1 while the results for the cold issue periods are shown in Figure 2.

Inspection of the graph of average excess returns for issues in the hot issue period shows that with exception of a very small negative average excess return for the sixth month after issue, excess returns are substantially positive for each month over the subsequent year. Of particular interest is the question of whether speculative bubbles as defined by Ritter (1984) occur. The implication of this theory is that speculative excess causes the price to rise shortly after listing. This rise would then be followed by sharp price declines in the aftermarket. The graph of the hot issue period shows a positive but declining excess return right up to the sixth month.

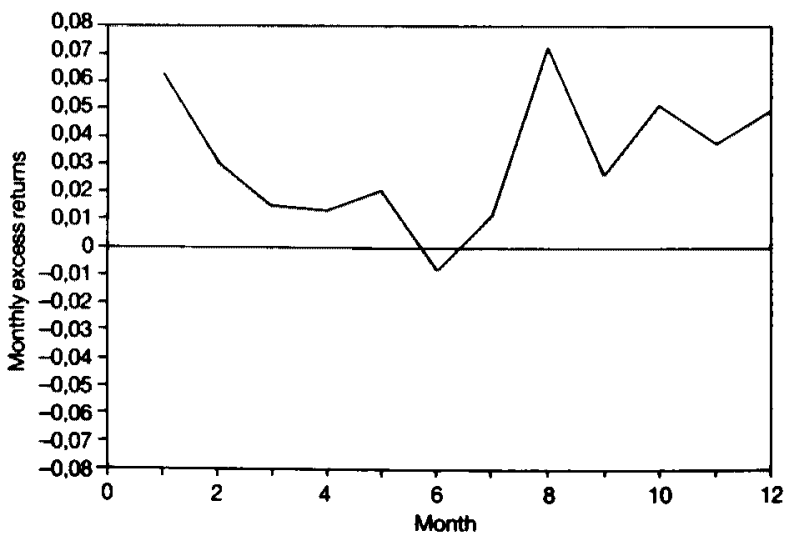

Figure 1 Average excess returns for hot periods

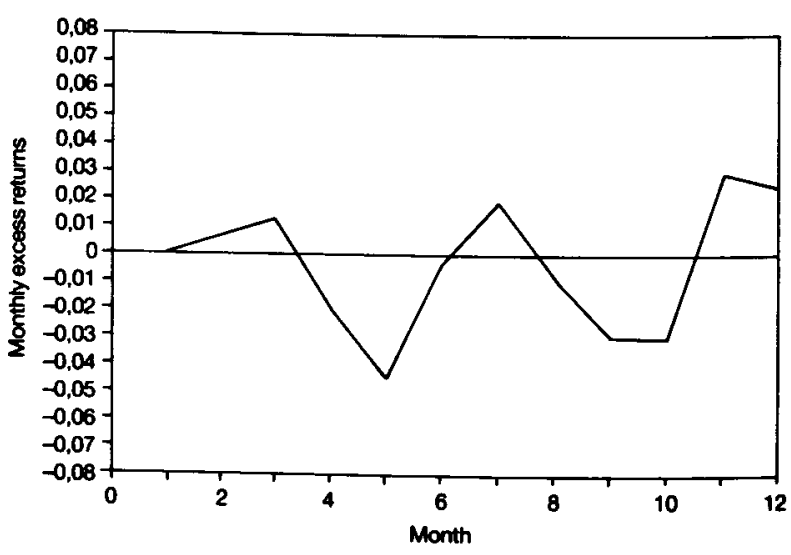

Figure 2 Average excess returns for cold periods 
Recall that the interpretation of excess returns imply that these are the returns over and above/below those priced according to the given level of risk as indicated by model (1). Consequently Figure 1 shows evidence that prices generally rise substantially for the first five months whereafter a levelling off, or, on average a very slight decline occured in the sixth month. Thereafter prices tended to rise fairly sharply resulting in an abnormal return peak of $7,2 \%$ per month in the eight month and remaining above the $2,5 \%$ per month level for the remainder of the year. This behaviour is not consistent with the speculative bubble hypothesis proposed by Ritter (1984) as there are no sharp price declines evident in the aftermarket associated with the hot issue period.

Figure 2 depicting the month to month performance of securities in the cold issue period show a different and somewhat more erratic picture.

Inspection of Figure 2 shows that small, but positive excess returns are evident for the first three months after issue, reaching $1,2 \%$ per month in month 3 . For the remainder of the year, months $4,5,6,8,9$ and 10 show negative excess returns with positive peaks in months 7 and 11. There is no obvious plausible reason for the erratic price behaviour after the third month of listings in cold issue periods. Hence it can only be concluded that no discernable price behaviour is evident over the remainder of the subsequent year. This is in contrast to the hot issue period where returns are found to be generally consistently superior in the aftermarket period.

\section{Opening premia and aftermarket performance}

Although the above results suggest that high opening premia are generally associated with a consistently superior aftermarket performance, a more direct test of this relationship is considered here.

The methodology used here was proposed by McDonald \& Fisher (1972). The population of new listings was partitioned by opening premia exceeding $50 \%$. A total of 21 shares with opening premia greater than $50 \%$ out of the 77 shares were identified here. The mean excess return of these shares for a one year period was tested against the corresponding mean excess return of the population of 77 shares. The sample mean of the 21 partitioned shares was $76 \%$ per annum while the mean of the population of 77 shares was $29 \%$ with a standard deviation of $86,9 \%$ per annum. This resulted in a $Z$ value of 2,478 which is significant at the $1 \%$ level.

This evidence suggests that issues with relatively larger opening premia generally have higher than average aftermarket excess returns over the subsequent year.

In order to assess how well the magnitude of opening premia correlates with the magnitude of aftermarket performance, the correlation coefficient between the opening premia and the excess returns one year subsequent to listing was computed for the series of 77 new issues. This resulted in a value of 0,287 which is significant at the $2,5 \%$ level implying a significant positive relationship exists between the size of the opening premium and the extent of aftermarket gains.
The above findings support the assertion made by several respondents to a survey by Barlow \& Sparks (1986), that in order for a share to have a successful performance after listing, it should make its debut with a relatively large opening premium.

\section{Opening premia and volumes traded}

It has been contended by Ying (1966) that share prices and trading volumes are joint products of a single market mechanism and should be considered together in the formulation of a model of stockmarket behaviour. In the context of new issues it is worth considering whether shares with relatively larger opening premia attract more speculative activity or vice versa.

In order to establish whether a significant relationship exists between volume traded and opening premia, volume statistics for each of the 77 shares were computed. These were obtained by summing the total volume of shares traded during the year subsequent to listing and scaling this amount by the number of shares issued at the listing date for each share.

The correlation coefficient between the opening premia and the volume statistics was found to be 0,32 . This is significant at the $1 \%$ level indicating that a significant relationship exists between the opening premia and the volumes traded in the aftermarket.

\section{Opening premia and systematic risk}

Although it has been established in an earlier section that the magnitude of opening premia is related to the magnitude of risk adjusted returns, this has no direct bearing on the possible relationship between opening premia and systematic risk as measured by beta.

This relationship is investigated here using the beta values estimated for each of the 77 shares over the subsequent year at monthly intervals as discussed in an earlier section. The appendix contains the beta estimates and their associated $R^{2}$ statistics. Although several of the $R^{2}$ and beta estimates are seen to be fairly small, this is a well known occurrence on the JSE and has been documented by Bradfield, Barr \& Affleck-Graves (1988) as well as several other researchers. This tends to imply that unique risk is dominant for shares with low $R^{2}$ over the year subsequent to listing.

The correlation coefficient between share beta's and their corresponding opening premia was found to be only 0,13 which is not significant even at the $20 \%$ level (considering a two-sided alternative). Hence no significant relationship was found to exist between opening premia and systematic risk.

\section{Aftermarket performance and the underwriter}

It has been suggested that there could be a significant difference in the aftermarket performance of shares underwritten by one organization compared to the performance of shares underwritten by another. A plausible reason for this is that conservative organizations tend to underwrite new listings of companies which are already mature and can thus expect lower growth than newer, more volatile companies. The 
shares of the latter companies, particularly those listed on the DCM, tend to be underwritten by less conservative organizations.

For the purpose of testing this hypothesis, only those underwriters were considered who underwrote five or more listings out of the 77 . Although 16 different organizations in total were involved in the underwriting of the 7 listings, only four of these underwrote five or more listings. This amounted to a sample of 35 listings.

Table 3 lists the four organizations and their mean excess returns over the subsequent year for the companies they underwrote during the sample period.

From Table 3 the mean excess return of the listings underwritten by Senbank and Standard MB appear to be substantially greater than those underwritten by Barclays MB and UAL. To determine whether the above means were statistically significant an Analysis of Variance test was performed on the sample.

Table 4 shows the details of the test.

The small $F$ ratio found in Table 4 is clearly not significant even at the $20 \%$ level. This implies that none of the above means are statistically different from the others. Even though it appears as if Senbank and Standard MB have mean returns far superior to the others, this in fact is misleading, their aftermarket performance (as measured by excess returns) is not significantly different from the others. The high variability of the new listings for these underwriters shown in Table 3 supports this conclusion.

\section{Consholon}

The results of our analysis have several implications for investors and speculators on the JSE. Our results suggest that abnormal returns do exist in the post-listings period of new issues, in particular, if hot issue periods are identified, that substantial abnormal returns have been found to occur during the year subsequent to listing in these periods. In cold issue periods, however, our results show average abnormal returns occurring up to the third

This 3 Average excess return based on underwriter

\begin{tabular}{lcccc}
\hline & \multicolumn{4}{c}{ Underwriter } \\
\cline { 2 - 5 } & \multicolumn{5}{c}{ Standard Barclays } \\
& Senbank & MB & MB & UAL \\
\hline Mean excess return & $68,7 \%$ & $74,1 \%$ & $7,3 \%$ & $7,1 \%$ \\
Standard deviation & $125,4 \%$ & $125,5 \%$ & $52,0 \%$ & $42,5 \%$ \\
No. of companies listed & 12 & 9 & 6 & 8 \\
\hline
\end{tabular}

Thlo 4 ANOVA tablo

\begin{tabular}{|c|c|c|c|c|}
\hline Source & $\begin{array}{l}\text { Sum of } \\
\text { squares }\end{array}$ & $\begin{array}{l}\text { Degrees of } \\
\text { freedom }\end{array}$ & $\begin{array}{l}\text { Mean } \\
\text { square }\end{array}$ & $F$ ratio \\
\hline Between underwriters & 34408 & 3 & 11469 & 1,094 \\
\hline Within underwriters & 325109 & 31 & 10487 & \\
\hline Total & 359517 & 34 & & \\
\hline
\end{tabular}

month after listing, but the average abnormal retums are only of the order of $1 \%$ per month. By contrast average abnormal returns in excess of $7 \%$ per month have been documented in the aftermarket of listings in the hot issue period.

Further our results indicate that a significant positive relationship exists between opening premia and some important behavioural characteristics in the aftermarket. In particular a significant relationship was found to exist between the opening premia and abnormal returns one year after issue. This implies that securities with high opening premia generally have relatively higher abnormal returns in their respective aftermarket periods. A significant relationship was also found to exist between the opening premia and the volume of shares traded during the subsequent one year post listing period. A plausible reason for this is that substantially more speculative activity is attracted to issues with higher opening premia.

No significant relationship was, however, evident between the opening premia and systematic risk of new issues. Finally no significant difference between the aftermarket performance of listings associated with the various underwriters in question was found to exist on the JSE.

\section{Notes}

: The t-statistic is computed using:

$$
t=\frac{E_{l} / \sqrt{n}}{S\left(E_{l}\right)} \quad \text { where the } E_{j \ell} \text { are estimated }
$$

\section{Reforomece}

Bradfield, D.J., Barr, O.D.I. \& Affleck-Graves, J.F. 1988. Asset pricing in small markets- The South African case. $S$. Afr. J. Bus. Mgmt., vol.19, 11-21.

Barlow, H. \& Sparks, R. 1986. A Study of the Pricing of New Equity Issues listed on the JSE. MBA Dissertation, University of Cape Town.

Blum, J.D. 1971. An Analysis of Initial Common Stock Offerings. Doctoral Dissertation, Michigan State University.

Davis, E.W. \& Grant, A.T.K. 1972. Small Business and the Capital Market. Moorgate and Wall Street, 48-63.

Harris, R.A. 1933. A re-analysis of the 1928 new issue boom. The Econ. J.,vol. 43, 453-459.

Ibbotson, R.G. 1975. Price performance of common stock new issues. J. Fin. Econ., vol.2, 235-272.

Logue, D.E. 1973. Premia on unseasoned equity issues: 1965-1969. J. Fin. Quant. Analysis, vol.8,90-103.

Lurie, R. 1941. The company promotion boom in South Africa, 1933-1938. The S. Afr. J. Econ., vol. 9, 265-273.

McDonald, J.G. \& Fisher, A.K. 1972. New-issue stock price behaviour. J. Fin., vol. 27, 97-102.

Relly, F.K. \& Hatfield, K. 1969. Investor experience with new stock issues. Fin. Analysts J., vol., 25, 73-80.

Richards, C.S. 1935. Company promotion in South Africa, 1933-1934. The S. Afr. J. Econ., vol.3, 229-248. 
Ritter, J.R. 1984. The 'Hot Issue' market of 1980. J. Bus., vol., 57, 215-240.

Rothman, J. 1973. An analysis of New Issues, 1st ed., London: Leopold Joseph.

Scott, P. 1971. Share Price Performance of Newly Quoted Companies. Sloan Dissertation, London Business School.

Stigler, G.J. 1964. Public regulation of the securities markets. The J. Bus., vol., 37, 117-142.

Underhill, L.G. 1981. Introstat, 3rd ed., Cape Town: Juta.

Vaughan, C.D., Grinyer, P.H. \& Birley, S.J. 1977. From

Private to Public, 1st ed., London: Woodhead Faulkner.

Williams, D.H. 1972. An Investigation into New Equity Issues on the London Stock Exchange: 1966-1970. M. Com.

Dissertation, University of Birmingham.

Wood, R. 1986. Raising Equity - An Analysis of New Issues and Right Issues in South Africa - Are underwriters facing enough risk? Technical Report, University of Cape Town.

Ying, C.C. 1966. Stock market prices and volumes of sales. Econometrica, vol. 34(3), 85-103.

Appendix Summary statistics of new issues over 1975-1986

\begin{tabular}{|c|c|c|c|c|c|}
\hline & Share & Beta & $R^{2}$ & $\begin{array}{l}\text { Opening } \\
\text { Premium }\end{array}$ & $\begin{array}{l}\text { Adjusted } \\
\text { Volume }\end{array}$ \\
\hline 1 & FS SAAIPLAAS & 1,07 & 0,07 & $-0,12$ & 0,16 \\
\hline 2 & DEELKRAAL & 1,07 & 0,21 & 0,59 & 0,10 \\
\hline 3 & FEDPROP & 0,09 & 0,03 & 0,03 & 0,47 \\
\hline 4 & ELANDSRAND & 0,19 & 0,00 & 0,47 & 0,04 \\
\hline 5 & ERGO & $-0,12$ & 0,02 & 0,26 & 0,23 \\
\hline 6 & KIMET & $-0,05$ & 0,00 & 0,25 & 1,08 \\
\hline 7 & CUSAF & 0,26 & 0,26 & 0,26 & 0,57 \\
\hline 8 & C I & 0,10 & 0,01 & $-0,03$ & 1,42 \\
\hline 9 & CLICKS & $-1,92$ & 0,40 & 0,45 & 0,69 \\
\hline 10 & SOUTH SUN & 0,82 & 0,14 & 0,33 & 1,14 \\
\hline 11 & SASOL & 0,35 & 0,04 & 0,54 & 0,67 \\
\hline 12 & DRG & 0,19 & 0,02 & 0,01 & 0,89 \\
\hline 13 & KAAPWYN & 0,46 & 0,19 & 0,17 & 0,65 \\
\hline 14 & XACTICS & 0,68 & 0,17 & 0,43 & 0,43 \\
\hline 15 & DAN PERKINS & 1,12 & 0,23 & 0,41 & 0,94 \\
\hline 16 & CENPROP & 0,89 & 0,43 & 0,03 & 1,16 \\
\hline 17 & MCALPINE & 0,86 & 0,38 & 0,45 & 0,60 \\
\hline 18 & SOLARSH & 0,05 & 0,01 & 0,15 & 0,82 \\
\hline 19 & ACROW & 0,51 & 0,20 & $-0,02$ & 0,31 \\
\hline 20 & H \& J CABLES & 0,10 & 0,02 & 0,22 & 0,69 \\
\hline 21 & ADK & 0,30 & 0,08 & 0,50 & 0,52 \\
\hline 22 & CBD PROP & 0,45 & 0,35 & 0,17 & 0,13 \\
\hline 23 & ENYATI & 0,46 & 0,08 & 0,00 & 1,30 \\
\hline 24 & ADVANCE & 0,22 & 0,02 & 0,39 & 0,04 \\
\hline 25 & OMNIA & 0,02 & 0,00 & 0,03 & 0,13 \\
\hline 26 & N BERNICA & 0,05 & 0,01 & $-0,08$ & 0,26 \\
\hline
\end{tabular}

Appendix Continued

\begin{tabular}{|c|c|c|c|c|c|}
\hline & Share & Beta & $R^{2}$ & $\begin{array}{l}\text { Opening } \\
\text { Premium }\end{array}$ & $\begin{array}{l}\text { Adjusted } \\
\text { Volume }\end{array}$ \\
\hline 27 & STANPROP & $-0,15$ & 0,02 & 0,36 & 0,06 \\
\hline 28 & PRU & 0,12 & 0,01 & 0,65 & 0,16 \\
\hline 29 & UMDONI & 0,21 & 0,07 & 0,08 & 0,24 \\
\hline 30 & RIH & 1,45 & 0,52 & 0,42 & 0,05 \\
\hline 31 & SCORE & 1,66 & 0,40 & 0,90 & 0,86 \\
\hline 32 & CAP PROP & 0,56 & 0,15 & $-0,10$ & 0,30 \\
\hline 33 & TDH & 0,08 & 0,01 & 0,29 & 0,51 \\
\hline 34 & EUREFIN & 0,52 & 0,06 & 0,00 & 0,15 \\
\hline 35 & CHANNEL & $-0,04$ & 0,00 & 0,05 & 0,04 \\
\hline 36 & BEATRIX & 1,68 & 0,39 & 0,34 & 0,68 \\
\hline 37 & MODDER B & 0,68 & 0,16 & 0,33 & 2,74 \\
\hline 38 & S. LIFE & 0,66 & 0,42 & 0,32 & 0,69 \\
\hline 39 & GROPROP & 0,46 & 0,14 & 0,05 & 1,84 \\
\hline 40 & BARPROP & 0,31 & 0,07 & 0,00 & 0,06 \\
\hline 41 & RANDEX & $-0,12$ & 0,00 & 0,73 & 1,23 \\
\hline 42 & HUDACO & $-0,25$ & 0,02 & 0,50 & 1,17 \\
\hline 43 & SPL & 0,59 & 0,05 & 1,67 & 1,31 \\
\hline 44 & NDH & 1,29 & 0,27 & 0,12 & 0,72 \\
\hline 45 & WEST WITS & 1,25 & 0,31 & 0,33 & 1,75 \\
\hline 46 & SUN INT & 0,11 & 0,01 & 0,50 & 0,51 \\
\hline 47 & CRULIFE & $-0,04$ & $\mathbf{0 , 0 0}$ & 0,25 & 1,08 \\
\hline 48 & SPRIDAG & 2,15 & 0,34 & 1,05 & 1,91 \\
\hline 49 & JUICY LUCY & 0,05 & $\mathbf{0 , 0 0}$ & 1,67 & 3,96 \\
\hline 50 & METLIFE & $-0,07$ & 0,00 & 0,22 & 0,66 \\
\hline 51 & LIFEGRO & 0,29 & 0,09 & 0,39 & 0,52 \\
\hline 52 & MAS HOLD & $-0,26$ & 0,02 & 0,50 & 1,05 \\
\hline 53 & METPROP & $-0,04$ & 0,00 & $-0,03$ & 3,66 \\
\hline 54 & VANSA & 1,73 & 0,27 & 0,09 & 0,95 \\
\hline 55 & PUNCH & 1,96 & 0,23 & 1,03 & 1,38 \\
\hline 56 & SUNPAK & 0,29 & 0,01 & 0,71 & 5,34 \\
\hline 57 & TEMPORA & $-0,03$ & 0,00 & 0,12 & 0,08 \\
\hline 58 & REICHMANS & 1,27 & 0,11 & 0,13 & 1,56 \\
\hline 59 & ТАMBOTI & 0,18 & 0,02 & 0,01 & 2,64 \\
\hline 60 & AOS & $-1,03$ & 0,11 & 0,38 & 1,64 \\
\hline 61 & MIDAS & $-0,12$ & 0,00 & 0,02 & 0,58 \\
\hline 62 & SPUR & 0,82 & 0,03 & 1,08 & 6,66 \\
\hline 63 & HOUSEWARES & 0,67 & 0,02 & 0,44 & 4,43 \\
\hline 64 & PACTAPE & $-0,42$ & 0,01 & 0,08 & 2,77 \\
\hline 65 & $T \& N$ & $-1,14$ & 0,04 & $-0,07$ & 0,79 \\
\hline 66 & PRES MED & $-0,84$ & 0,12 & 0,53 & 0,67 \\
\hline 67 & FABLIB & $-1,05$ & 0,22 & 0,06 & 0,92 \\
\hline 68 & MIKES & $-0,72$ & 0,01 & 0,62 & 2,78 \\
\hline 69 & C-MATIC & $-0,06$ & 0,00 & 1,60 & 0,29 \\
\hline 70 & CASHBUILD & 0,58 & 0,02 & 0,64 & 0,66 \\
\hline 71 & POINTER & 0,79 & 0,07 & 0,17 & 1,9 \\
\hline 72 & H.J. JOEL & $-0,15$ & 0,00 & 0,67 & 0,46 \\
\hline 73 & MEDI-CLINIC & 0,42 & 0,06 & 0,00 & 0,08 \\
\hline 74 & S E RAND GOLD & $-0,20$ & 0,00 & 0,77 & 2,42 \\
\hline 75 & POTCH GOLD & $-0,12$ & 0,00 & 0,43 & 3,60 \\
\hline 76 & SUB NIGEL & 0,48 & 0,02 & 1,03 & 1,83 \\
\hline 77 & FURN FAIR & 1,91 & 0,45 & 0,50 & 2,86 \\
\hline
\end{tabular}

